\title{
HYDROPOWER DEVELOPMENT AND ECONOMIC GROWTH IN NEPAL
}

Herath Gunatilake, Priyantha Wijayatunga, and David Roland-Holst

NO. 70

June 2020

\section{ADB SOUTH ASIA WORKING PAPER SERIES}





\section{ADB South Asia Working Paper Series}

\section{Hydropower Development and Economic Growth in Nepal}

Herath Gunatilake, Priyantha Wijayatunga, and

David Roland-Holst

No. 70 | June 2020
Herath Gunatilake is a former director, Sustainable Development and Climate Change Department, and Priyantha Wijayatunga is currently the energy sector director, South Asia Department of the Asian Development Bank (ADB). David Roland-Holst is professor of economics at University of California Berkeley. The authors thank Adam Soliman for his excellent research assistance and colleagues at ADB for productive discussions. 
(C) 2020 Asian Development Bank 6 ADB Avenue, Mandaluyong City, 1550 Metro Manila, Philippines

Tel +632 8632 4444; Fax +63286362444

www.adb.org

Some rights reserved. Published in 2020.

Printed in the Philippines

ISSN 2313-5867 (print), 2313-5875 (electronic)

Publication Stock No. WPS200161-2

DOI: http://dx.doi.org/10.22617/WPS200161-2

The views expressed in this publication are those of the authors and do not necessarily reflect the views and policies of the Asian Development Bank (ADB) or its Board of Governors or the governments they represent.

ADB does not guarantee the accuracy of the data included in this publication and accepts no responsibility for any consequence of their use. The mention of specific companies or products of manufacturers does not imply that they are endorsed or recommended by ADB in preference to others of a similar nature that are not mentioned.

By making any designation of or reference to a particular territory or geographic area, or by using the term "country" in this document, $\mathrm{ADB}$ does not intend to make any judgments as to the legal or other status of any territory or area.

This work is available under the Creative Commons Attribution 3.0 IGO license (CC BY 3.0 IGO) https://creativecommons.org/licenses/by/3.0/igo/. By using the content of this publication, you agree to be bound by the terms of this license. For attribution, translations, adaptations, and permissions, please read the provisions and terms of use at https://www.adb.org/terms-use\#openaccess.

This CC license does not apply to non-ADB copyright materials in this publication. If the material is attributed to another source, please contact the copyright owner or publisher of that source for permission to reproduce it. ADB cannot be held liable for any claims that arise as a result of your use of the material.

Please contact pubsmarketing@adb.org if you have questions or comments with respect to content, or if you wish to obtain copyright permission for your intended use that does not fall within these terms, or for permission to use the ADB logo.

The ADB South Asia Working Paper Series is a forum for ongoing and recently completed research and policy studies undertaken in $A D B$ or on its behalf. It is meant to enhance greater understanding of current important economic and development issues in South Asia, promote policy dialogue among stakeholders, and facilitate reforms and development management.

The ADB South Asia Working Paper Series is a quick-disseminating, informal publication whose titles could subsequently be revised for publication as articles in professional journals or chapters in books. The series is maintained by the South Asia Department. The series will be made available on the ADB website and on hard copy.

Corrigenda to ADB publications may be found at http://www.adb.org/publications/corrigenda.

Notes:

In this publication, "\$" refers to United States dollars and "NRs" refers to Nepalese rupees.

Printed on recycled paper 


\section{CONTENTS}

TABLES AND FIGURES

ABSTRACT

$\begin{array}{ll}\text { I. INTRODUCTION } & 1\end{array}$

II. OVERVIEW OF NEPAL'S ELECTRICITY SECTOR 2

$\begin{array}{ll}\text { III. POLICY SCENARIOS } & 4\end{array}$

$\begin{array}{ll}\text { A. Baseline } & 4 \\ \text { B. Investment in Hydropower for Domestic Growth and Export } & 4 \\ \text { C. Sensitivity Analysis } & 5\end{array}$

$\begin{array}{lll}\text { IV. } & \text { RESULTS AND DISCUSSIONS } & 7\end{array}$

A. Macroeconomic Results for the Central Scenario $\quad 7$

B. Stochastic Scenario Analysis 9

V. CONCLUSIONS $\quad 12$

$\begin{array}{ll}\text { REFERENCES } & 13\end{array}$ 


\section{TABLES AND FIGURES}

\section{TABLES}

1 Major River Basin of Nepal and Their Hydropower Potential 3

2 Economic Expansion in Nepal, Hydro20 Scenario $\quad 7$

3 Poverty Impacts of Hydro20 8

4 Avoided Emissions by Hydro20 8

5 Stochastic Scenario Estimates Percent Change in Real GDP Baseline 2030, 11 Legendre Method

6 Stochastic Scenario Estimates Percent Change in Real GDP Baseline 2030, 11 Hermite Method

\section{FIGURES}

1 Cumulative Hydropower Capacity in the Mekong River Basin 5

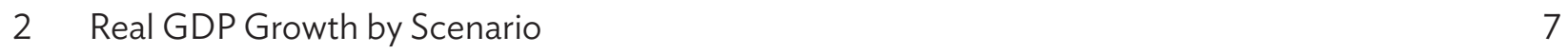




\begin{abstract}
Hydropower development is a controversial topic as it potentially has significant environmental and social impacts. However, hydropower has received favorable consideration recently due to its potential to mitigate climate change. This study adds to the ongoing debate on hydropower development, taking on Nepal as a case study. It uses a computable general equilibrium model to examine the macroeconomic impacts of expanding Nepal's hydropower potential. In order to have a better understanding of the macroeconomic implications of large-scale hydropower development, the study takes into account exogenous oil price risks and external market opportunities to evaluate Nepal's hydroelectric development options over 2 decades. The basic scenario analysis was complemented with an advanced Monte Carlo simulation to understand the interactive effects of oil price changes with varying degree of hydropower generation. Results show that hydropower development will significantly increase economic growth in Nepal. In the long run, hydropower generation expansion increases domestic incomes, lowers real domestic energy prices, significantly alleviates poverty, and provides insurance against oil price increases. Moreover, this study shows that Nepal has potential to significantly contribute in providing environmental services to the South Asian region by delivering clean, renewable energy while mitigating climate change.
\end{abstract}





\section{INTRODUCTION}

One-fifth of the global electricity supply comes from hydropower, and hydropower development has promoted and helped shape economic growth in many countries such as Bhutan, Canada, Norway, and the United States (World Bank 2009). Hydropower can play an important role to address growing demand worldwide for clean, reliable, and affordable energy. Moreover, properly designed and implemented multipurpose water infrastructure projects also offer other development opportunities such as irrigation, fisheries, and domestic and industrial water supply for developing nations (World Bank 2009; Billington and Jackson 2006; ICOLD 2010). Hydropower avoids use of carbon-intensive energy sources such as coal, oil, and gas, and also helps integration of other intermittent renewable energybased power generation sources such as solar and wind power into the main grid, moving the economies toward a low-carbon development path.

However, hydropower projects are complex and are often associated with serious economic, social, and environmental risks. These risks are often cited by those opposed to large-scale hydropower projects by stakeholders such as civil society organizations, communities, donor agencies, and governments in developed countries. The Report of the World Commission on Dams (WCD 2000) was a milestone in terms of growing opposition to large dam projects. While acknowledging the benefits of large dams, the WCD report highlighted that in too many cases, an unacceptable and often unnecessary environmental and social costs have been incurred in securing such benefits. Findings of this report have had a major impact on hydropower development; many development financing institutions hesitated supporting hydropower development for about a decade. A World Bank report titled "Directions in Hydropower" (World Bank 2009) is indicative of changes taking place on this trend. The report argues that lessons from the past, together with emerging global energy trends, call for a renewed role for hydropower in global energy developments.

Thus, there is a renewed interest in hydropower development among major stakeholders, but the debate on its costs and benefits continues. For example, Ansar et al. (2014) claim that cost estimates of past hydropower projects have been systematically below actual costs as they have not properly incorporated inflation, debt servicing, and environmental and social costs of large dams. The article also predicts time and cost overruns of future large dams. It concludes that in many countries large hydropower dams are too costly to build to deliver positive risk-adjusted returns unless suitable risk management measures are imbedded in project designs. Despite the fact that whether time and cost overruns are unique to hydropower or common to all the large civil work projects remains an interesting research question, Ansar et al. (2014) cast doubts in the minds of policy makers about hydropower.

This paper contributes to the ongoing debate on hydropower, taking on Nepal as a case study. It uses a general equilibrium model to study the economic and environmental impacts of Nepal's hydropower development options over 2 decades. This model takes into account electricity export opportunities to neighboring countries considering conventional energy price risks. Its sensitivity analysis, which uses the Monte Carlo framework, demonstrates that Nepal can significantly stimulate economic growth within plausible scenarios of oil price changes and investment strategy, through national and international joint venture development of its hydropower potential. In the long run, hydropower generation expansion, together with the necessary transmission infrastructure development, will significantly increase national income and make, domestic energy cheaper. It also reduces poverty more effectively than electricity subsidies. Moreover, this study shows that Nepal has a potential to significantly contribute in providing environmental services to the South Asian region, by delivering clean, renewable energy and by climate change mitigation. 


\section{OVERVIEW OF NEPAL'S ELECTRICITY SECTOR}

The energy sector plays a very important role in economic development and evidence shows that expanding the electricity sector contributes to economic growth in many countries. The underperforming electricity sector in Nepal, with inadequate and unreliable supply of poor-quality electricity, was a major development constraint. This situation has been improving, but even today basic energy needs of Nepali citizens are only being met partially. The energy sector is still dominated by traditional sources, where fuel wood accounts for over three-quarters of total energy consumption. Nepal has no known oil or gas resources and all fossils fuels are imported. As of 2019, about $89 \%$ of the population has access to electricity, but the supply is of poor quality and unreliable. Despite the dramatic increase in per capita electricity consumption, from 63 kilowatt-hours (kWh) per annum in 2000 to $177 \mathrm{kWh}$ per annum in 2018, it remains among the lowest in the world; Nepal's per capita electricity consumption is onetwentieth of the global average.

Nepal's economic growth was less than 4\% per annum during the 2000s. This slow growth is partially attributed to shortages in the supply of electricity for both traditional and modern industries. This situation has been changing, as it recorded about $6 \%$ growth in 2013 and about $7.3 \%$ growth on average from 2016 to 2018, after a significant slowdown in 2014 and 2015 mainly resulting from the impacts of the earthquake. Specifically, contribution from both the agricultural and industrial sectors to the gross domestic product (GDP) has decreased in the past 2 decades. While the relative contribution from the agricultural and industrial sectors declined, the services sector has grown and currently accounts for the largest share of Nepal's economy. In 2017, services accounted for 51.6\% of GDP, followed by agriculture (26.2\%) and industry (13.4\%). It is believed that the recent improvements in electricity supply to the industrial and service sectors have contributed to better economic growth. This trend in electricity sector growth is expected to continue along with rapid urbanization and a growing number of energy-intensive industries. The unconstrained demand for electricity is expected to increase from an estimated 10,138 gigawatt-hours (GWh) in 2019-2020 to 31,196 GWh in 2029-2030 (Nepal 2019).

The total installed generation capacity in Nepal is only 1,182 megawatts (MW) against a peak electricity demand of 1,320 MW in fiscal year 2018-2019. Of this, the Nepal Electricity Authority (NEA) owned $621 \mathrm{MW}$ (generating 34\% of total sold electricity) while private investors owned $560 \mathrm{MW}$ of the total installed capacity (generating $29 \%$ of total sold electricity). The remaining requirements were satisfied by importing electricity from India (38\% of total electricity sale, maximum import of about $596 \mathrm{MW}$ ). Electricity generation capacity in $\mathrm{Nepal}$ is rapidly increasing. In terms of the recent progress in hydropower development, survey licenses for 302 projects with a total capacity of 15,885 MW have been already issued, out of which 172 projects have secured generation licenses and construction is ongoing for total capacity of 4,642 MW. Power purchase agreements have been completed for 244 projects with total capacity of 4,138 MW.

NEA, Nepal's energy agency, is a vertically integrated, state-owned utility responsible for electricity generation, transmission, and distribution. NEA is the sole off-taker of generation from other parties, including private sector-owned generation. The poor financial health of the NEA as the only off-taker has therefore imposed significant fiscal burden on the government and constrained the sector's capacity to mobilize sufficient investments. The vertically integrated structure of NEA, along with its poor creditworthiness and lack of a mature regulatory environment, have become major constraints to higher level of private investments in large-scale hydropower projects. There has been significant progress in NEA's performance in recent years; however, these achievements are not likely to reap intended benefits in the longer run unless key sector challenges and constraints are addressed. Two major issues have a direct bearing to this problem: (i) inadequate planning, policy, and regulation and (ii) inadequate capacity and poor governance leading to underinvestment and difficulty in sustaining the growth of the 
power sector (ADB 2018). The challenge for the energy sector is to increase investment, which requires creating an enabling investment environment governed by a transparent and independent regulatory process providing a level playing field for all stakeholders. In this regard, expeditious operationalization of recently established Electricity Regulatory Commission is critical.

Electricity prices in Nepal had been kept too low and below cost-recovery levels in the past in absence of adequately independent regulatory regime. However, NEA was able to generate an operating profit in 2018 due to actions taken in the recent past including bringing an end to load-shedding, controlling operational expenses, and implementing financial reform measures. Low average price of imported electricity also contributed to the profitability. Yet, NEA still has about NRs10 billion in cumulative losses.

Nepal's water resources endowments are extraordinary. It endows approximately 6,000 rivers with a total length of 45,000 kilometers $(\mathrm{km})$. Average water runoff from these rivers is about 220 billion cubic meters annually. Based on the water resources availability, it Nepal's technical potential for hydropower has been estimated to be 83 gigawatts (GW). Usually all the technically potential water resources will not be developed due to other constraints. Hence, about $42 \mathrm{GW}$ is considered economically viable. The major river basins are Sapta Koshi, Karnali, Sapta Gandaki, Mahakali, and the Southern rivers (Gurung and Oh 2011); their respective generation capacities are presented in Table 1.

Table 1: Major River Systems of Nepal and Their Hydropower Potential

\begin{tabular}{lcccrr}
\hline \multicolumn{1}{c}{ Major River Basin } & Theoretical Potential & \multicolumn{2}{c}{ Technical Potential } & \multicolumn{2}{c}{ Economic Potential } \\
\hline & Megawatts & Project sites & Megawatts & Project sites & Megawatts \\
\hline Sapta Koshi & 22,350 & 53 & 11,400 & 40 & 10,860 \\
\hline Sapta Gandaki & 20,650 & 18 & 6660 & 12 & 5270 \\
\hline Karnali and Mahakali & 36,180 & 34 & 26,570 & 9 & 25,125 \\
\hline Southern Rivers & 4110 & 9 & 980 & 5 & 878 \\
\hline Total & 83,290 & 114 & 45,610 & 66 & 42,133 \\
\hline
\end{tabular}

Source: K.C. Surendra et al. 2010. Current status of renewable energy in Nepal: Opportunities and challenges. Renewable and Sustainable Energy Reviews, 15 (2011).

Nepal is strategically located between two largest countries in Asia: India and the People's Republic of China (PRC). These two countries are facing annual demand for electricity of about 5 million GWh. Bangladesh is facing growing energy demand and it is also energy-deficient. Demand within Nepal is also growing rapidly. In addition to domestic and industrial use, Nepal also has good potential to use electricity for transportation. So far, Nepal has developed less than $1.2 \mathrm{GW}$ of hydropower, which is a tiny fraction of the total economic potential. Even with the ongoing hydropower developments, about $88 \%$ of the economic potential of hydropower is available for further development. India, the PRC, and other neighboring Asian countries like Bangladesh could easily absorb any additional supply of electricity over and above the needs of Nepal, provided that appropriate transmission infrastructure is in place. This paper models the Nepal's economy using a state-of-the-art forecasting model to understand the economic impacts of sizable hydropower development with plausible assumption in the following section. 


\section{POLICY SCENARIOS}

As explained earlier, Nepal has one of the largest hydropower potentials, both per capita and per unit of GDP. However, realizing this potential is a daunting task due the variety of constraints. The country faces a vast array of institutional, logistical, and profitability constraints for the public and private sector investments in hydropower development. These can be considered as supply side limitations and are aggravated by inadequate direct and indirect supporting infrastructure and overinvestment in inefficient power- generating plants. Thus, Nepal has been caught in a low level of investment equilibrium trap. The end results are imported energy dependency, power shortages, and chronic reliability problems (e.g., rationing, system failures). These are characteristics of long-lasting and widespread energy poverty (Nepal and Jamasb 2011). This situation is rapidly changing but resolving the capacity, governance, poor planning issues, and creating a level playing field for all stakeholders, along with operationalizing a better regulatory system, is necessary when injecting a sizable investment into the power sector to break the low-level investment equilibrium. The following section describes the plausible scenarios for expanding the hydropower sector in Nepal.

\section{A. Baseline}

As explained in an annex of H. Gunatilake and Roland-Holst (2013)', the Nepal computable general equilibrium (CGE) model was designed to examine economy-wide interactions including economyenvironment linkages. The 2010 Nepal Social Accounting Matrix (SAM) was used to develop the CGE model and the detailed equations of the model are completely documented in $\mathrm{H}$. Gunatilake and RolandHolst (2013). A CGE model is a system of simultaneous equations that simulate interactions between households and firms in factor and commodity markets. In such models, prices serve as the conveyer of the possible interactions among the different sectors. Taxation and government spending, interest rates, exchange rates, and trade among partners are also incorporated with varying degrees of detail. In addition, the closing conditions are imposed in the model to quantify for economy-wide resource allocation, production, and income determination.

The model used for this work was constructed according to generally accepted specification standards, implemented in the General Algebraic Modeling System (GAMS) programming language, and calibrated to the new Nepal SAM estimated for year 2010. ${ }^{2}$ The result is a single economy model calibrated over the 20-year year time path from 2010 to 2030. ${ }^{3}$ The World Bank, International Monetary Fund, and Oxford Econometrics have estimates that show that Nepal's potential rate of real economic growth is $4.5 \%$ per annum, over the next 2 decades. As mentioned earlier, Nepal's growth prospects have changed since 2016, but given the very low growth in 2014 and 2015 and future possibilities of similar fluctuations, $4.5 \%$ was considered to be a reasonable baseline.

\section{B. Investment in Hydropower for Domestic Growth and Export}

Of the $83 \mathrm{GW}$ in physical potential, slightly more than half is estimated to be economically feasible (Surendra et al. 2010). This assessment considers this estimate as the basis for developing plausible scenarios. Development of this total economic potential within a 20 -year period was considered impractical given the various constraints in the power sector. In the analysis, a scenario where Nepal

\footnotetext{
An early version of this work was uploaded in the internet as Berkeley University discussion paper.

See Meeraus et al. (1992) for GAMS.

3 The present specification is one of the most advanced examples of this empirical method, already applied to over 50 individual countries and/or regions.
} 
realizes $20 \%$ of its economically viable physical potential by 2030 is considered. This may still seem a major transformation in Nepal's power sector in a short period of time. However, as Figure 1 suggests, other Asian regions have shown that rapid development of hydropower is still feasible, but there are vast differences between Nepal and countries along the Mekong River. Rapid development of hydropower resources in Bhutan has also shown that it is feasible to develop hydropower in a short period of time. These examples provide some comfort for our assumptions on hydropower development in Nepal. Our assessment also assumes the necessary transmission infrastructure is also built together with the power generation capacity. Investment expenses are assumed to be in the initial periods by external private sector investment and public sector borrowing. This scenario is termed "Hydro20" in the discussion below.

Figure 1: Cumulative Hydropower Capacity in the Mekong River Basin

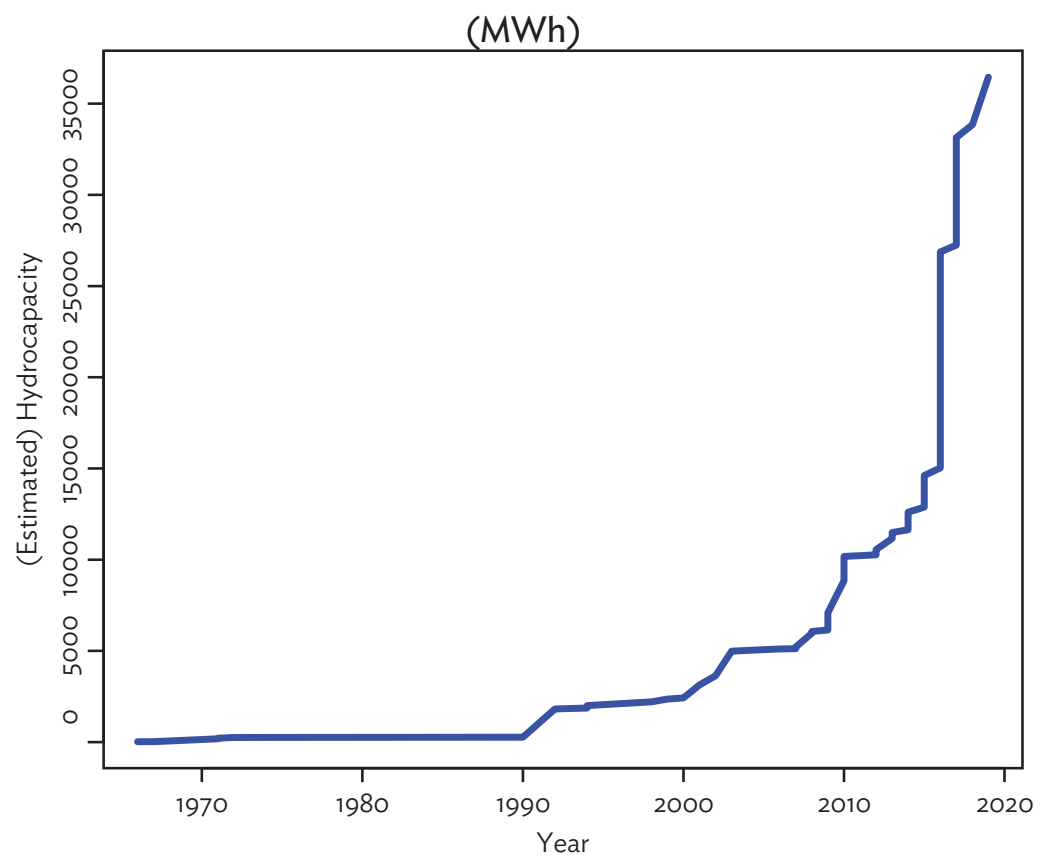

$\mathrm{MWh}=$ megawatt-hour.

Sources: World Bank, 2010; MRC, 2010; King et al. 2007.

\section{Sensitivity Analysis}

Twenty percent of Nepal's economic potential of hydropower is a massive build-up from the existing power generation capacity. As results demonstrate in the next section, Hydro20 is an attractive prospect for Nepal. However, the realization of Hydro20 depends on a number of uncertainties. First and foremost is the degree to which the "20\% of potential" goal can be realized in a short span of time. Cost of alternative energy for electricity production is the other important source of uncertainty. Low cost of fossil fuels will reduce the cost effectiveness of hydropower. Very few experts expect falling oil prices as leading energy institutions like the International Energy Agency have sharply increased their trend estimates for oil prices over the last decade. While oil price is expected to increase in the future, it is particularly strange that Nepal heavily depends on fossil fuels for electricity generation despite large endowments of water resources. In this context, hydropower development should provide insurance against oil price increase. 
This paper presents an analysis based on an advanced hybrid of Monte Carlo simulation to enhance our understanding of the risks posed by oil price changes and degrees of realization of economic potential hydropower. The technical detail of our Monte Carlo analysis is given in H. Gunatilake and RolandHolst (2013). As fully explained in H. Gunatilake and Roland-Holst (2013), this analyses use recent methodological improvements applied by Hermeling et al. (2013) in stochastic impact assessment, taking into consideration the impact of continuous variation in scenario specification as well as exogenous variables such as global energy prices. This analysis allows estimation of robustness for proposed energy development strategies and its confidence intervals in relation to the economic impacts of such strategies. In the energy field, reliability analysis is widely used, but with different levels of sophistication. Of the analyses, the most advanced is the reliability analysis of the technical system, conducted not only before and during energy system development but also during operation of these systems. The other most sophisticated method is the financial analysis of energy investments, using "stress test" accounting models in order to evaluate the risk associated with assumptions on financial aspects (ADB 2013). We now add stochastic project impact assessment to this exercise, with the use of advanced methods of Bayesian analysis mainly to test policy reliability. 


\section{RESULTS AND DISCUSSIONS}

\section{A. Macroeconomic Results for the Central Scenario}

The purpose of this study is to estimate impacts of potential hydropower expansion on the long-term economic growth in Nepal. Economic impact results are summarized in this subsection by comparing baseline growth and the growth under the Hydro 20 scenario in which hydroelectric capacity is expanded by $20 \%$ of the country's estimated economic potential. The estimated macroeconomic impacts would be impressive, as summarized in Figure 2 and Table 2, if Nepal's generation capacity expands by 20\% of its economically viable physical potential within a 10 -year time period.

Figure 2: Real GDP Growth by Scenario

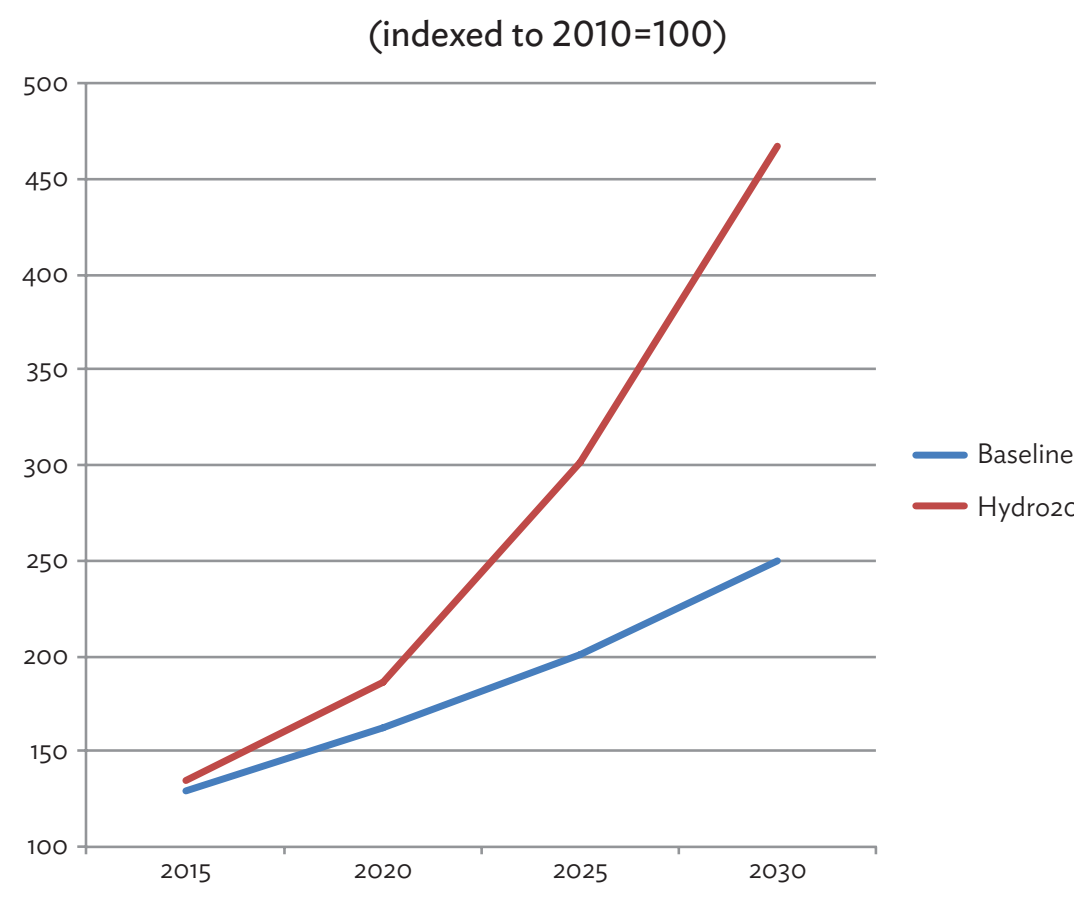

GDP = gross domestic product.

Source: Authors' estimates.

Table 2: Economic Expansion in Nepal, Hydro20 Scenario

\begin{tabular}{|c|c|c|c|c|}
\hline \multirow[t]{2}{*}{ Economic Indicator } & \multicolumn{4}{|c|}{$\begin{array}{l}\text { Percentage Change from the Baseline in } 2012 \\
(\%)\end{array}$} \\
\hline & 2015 & 2020 & 2025 & 2030 \\
\hline Real gross domestic product & 4 & 15 & 50 & 87 \\
\hline Real output & 3 & 18 & 61 & 108 \\
\hline Real per capita consumption & 14 & 15 & 35 & 66 \\
\hline Exports & 1 & 44 & 164 & 285 \\
\hline Imports & 17 & 37 & 137 & 298 \\
\hline
\end{tabular}

Source: Authors' estimates. 
As expected, the results in Table 2 and Figure 2 clearly demonstrate the long-term economic benefits of expanding Nepal's hydroelectric capacity. Expanding the country's hydropower generation by 20\% of the economic potential would result in an $87 \%$ increase of real GDP by 2030 above the baseline growth. Moreover, real output increases by more than $100 \%$ than the baseline, and real per capita household consumption is $66 \%$ higher. Investments in early years draw a large flow of capital resulting in appreciation of Nepal's currency. As a result, exports record slow growth in initial years. As hydropower exports start after few years, exports bounce back and export revenue becomes a primary driver of foreign exchange earnings. Imports also show a similar pattern of slow growth at the beginning due to slow income growth. Imports grow significantly toward 2025-2030 due to the higher purchasing power of citizens. The results indicate that leveraging both external savings and demand is required to realize the full economic potential of Nepal's hydropower capacity. Using the available information on poverty elasticity of growth, we also estimated the poverty impact of growth under the Hydro20 scenario. Table 3 shows that impact is very significant with extreme poverty coming down by a factor of 2 to 4 .

Table 3: Poverty Impacts of Hydro20

\begin{tabular}{lcc}
\hline Poverty Line & \multicolumn{2}{c}{$\begin{array}{c}\text { Below Poverty Line Population } \\
\text { (million) }\end{array}$} \\
\hline Business as Usual & Hydro20 \\
\hline \$1.25 per day & 8.37 & 2.0 \\
\hline 2.00 per day & 13.39 & 6.69 \\
\hline
\end{tabular}

Source: Author's estimates.

To illustrate the environmental benefits of Hydro20, we estimated the benefits of avoided carbon dioxide $\left(\mathrm{CO}_{2}\right)$ and other air pollutants assuming that the Hydro20 capacity will lead to avoidance of coal-fired power plants or coal-based power imports, considering that the power generation system in India is dominated by coal. India is likely to be the main importer of excess hydropower from Nepal or the supplier of power to Nepal when the latter faces power shortages. Estimated avoided air pollinating emissions are given in Table 4. These estimates were made with plausible assumptions which include that except $\mathrm{CO}_{2}$, other pollutants are controlled using the best available technologies in coal-fired power plants.

Table 4: Avoided Emissions by Hydro20

\begin{tabular}{cc}
\hline Pollutant & $\begin{array}{c}\text { Emissions } \\
\text { (tons/day) }\end{array}$ \\
\hline $\mathrm{CO}_{2}$ & 224120.9 \\
\hline $\mathrm{SO}_{2}$ & 2884.2 \\
\hline $\mathrm{NO}_{2}$ & 3548.2 \\
\hline $\mathrm{PM}_{10}$ & 7428.5 \\
\hline
\end{tabular}

$\mathrm{CO}_{2}=$ carbon dioxide, $\mathrm{SO}_{2}=$ sulfur dioxide, $\mathrm{NO}_{2}=$ nitrogen dioxide,
$\mathrm{PM}_{10}=$ particulate matter.
Source: Author's estimates.

In addition to hydropower, dams offer capacity to store water and therefore support flood control and augment dry season water flows. In montane regions, dams complement the environmental services of nature's second-largest fresh water storage facility (after groundwater), ice and snow. Nearly one-fifth of the global population relies on contributions from snow and glacier melt for their water supply (Barnett 
et al. 2005). Moreover, it has become apparent that long-term climate-induced temperature and precipitation changes will significantly affect the hydrology of montane regions around the world (Cruz et al. 2007, Immerzeel et al. 2009). Large rivers such as the Indus, Sutlej, Ganges, Arun, Brahmaputra/ Tsangpo, Mekong, Yangtze, and Yellow are essential for agriculture and energy generation, and are the pathways for soil-remediating sedimentation.

As already observed, glaciers' ability to store water during rainy season and slow release during the dry season has been diminishing due to climate change. Heavy rains within short periods of time have also been intensifying downstream flood damages. Plateaus in the Himalayas and adjacent to the Tibet Autonomous Region, the source of several major Asian rivers, support a population of more than 1 billion people (Ives and Messerli 1989) whose livelihoods depend on dry season water flows. A set of reservoirs along these rivers can help regulate water flows to reduce flood damage as well as to augment dry season water flows benefiting this large population. The use of hydropower dams as a means of climate adaptation, however, need further research focusing on technical feasibilities.

\section{B. Stochastic Scenario Analysis}

As discussed above, the significant economic and other benefits of hydropower development in Nepal are clear. However, there are number of uncertainties related to this large-scale project. First and foremost is securing financing and overcoming various institutional and capacity barriers to construct about $8.4 \mathrm{GW}$ generation capacity in around a 10-year time period. What would be the magnitude of economic achievements if the Hydro20 initiative achieves less than $20 \%$ of economically feasible national hydropower potential? In an unlikely scenario, if the growth of the hydropower is slower than baseline expectations, what would be the economic growth prospects for Nepal? In order to shed better light on these questions, this paper considers a continuous range of expectations for hydropower development in Nepal.

There are other exogenous macroeconomic variables which can affect the performance of the power sector. This type exogenous "shocks" or changes in state variables that have important implications for power sector and the economy can be beyond the control of policy makers. In this context, a second category of uncertainties include the economic performance of potential power-importing neighboring countries, global economic downturns like the 2008 recession, political instabilities in South Asian region, and oil price shocks. Incorporating some of the exogenous factors is not feasible in a computable general equilibrium (CGE) framework. In this paper, we consider one of the most important exogenous factors - global prices of fossil fuels. On one hand, fossil fuels are needed for a functioning economy (transport, cooking, etc.); on the other hand, fossil fuels are substitute for hydropower. Nepal does not have significant domestic fossil fuel potential, and it is a price taker in the global fuel market. Therefore, global fossil fuel prices have important implications for economic growth in Nepal. How can we assess the risk of oil price uncertainty for the country's growth within the context of Hydro20?

Such questions have been effectivelyaddressed with Monte Carlo methods of "sensitivity" analysis. Monte Carlo methods usually run hundreds or even thousands of model simulations with varying underlying values of scenario conditions and external variable values. This paper uses a more sophisticated methods of Gaussian Quadrature (GQ) (see H. Gunatilake and Roland-Holst 2013 for details), which improve the both the resource requirements and precision of the process.

This paper applies the GQ methodology for both Hydro20 scenario variations and exogenous oil price shocks. Two different variants of GQ methods-Legendre and Hermite-were used in Monte Carlo simulations. Technical details of Legendre and Hermite methods are fully explained in the $\mathrm{H}$. Gunatilake and Roland-Holst (2013) discussion paper. Tables 5 and 6 report the simulation results. Variational assumptions for both sensitivity variables are the same in both cases. In the case of Hydro20 scenario variations, this paper assumes that electric power capacity growth varies from $5 \%$ to $20 \%$ of the 
economically feasible physical potential with $1.5 \%$ incremental change. On the oil price side, we assume global oil prices increase to twice their current real value by 2030 or, at the other extreme, fall by $50 \%$. The general finding is consistent with our reference case, i.e., hydropower development can be a potential facilitator for economic growth in $\mathrm{Nepal}$, even in the context of significant uncertainly regarding generation capacity additions and extreme changes in oil prices.

As shown in the Hydro20 reference scenario, expanding the country's hydropower capacity would be a potent stimulator for economic growth, and the stochastic results reinforce this across a continuous spectrum of sector promotion (Table 5). Even a $5 \%$ increase in economically viable hydropower capacity would increase the cumulative GDP growth (last column) by $13 \%-25 \%$, but more resolute measures of $20 \%$ increase in capacity would increase the cumulative GDP by $25 \%-91 \%$. Note that the large differences in these ranges are due to the impacts of oil prices changes. In Table 5, first column, first row number (84\%) shows cumulative economic growth at 2030 when $20 \%$ of the economically feasible capacity of hydropower is developed and oil price doubled from the base. The first column, last row number (91\%) is the growth when oil price declined by $50 \%$, and $20 \%$ of the economically feasible physical potential of hydropower is fully realized. In the high oil price scenario (first row), the cumulative GDP increases by nearly 6.5 times (from $13 \%$ to $84 \%$ ) as generation capacity reaches the assumed full capacity. The same capacity expansions under the low oil price scenario (last row) only result in growth by about 4 times. These results help in understanding the interactive impact of oil price hikes and hydropower expansion on the economy. They show, on one hand, that negative impacts of oil price hike can be substantially compensated by hydropower expansion. On the other hand, for any level of hydropower expansion, lower oil prices provide higher growth benefits.

One important observation that can be made is that the aggregate growth dividend of hydropower development is nonlinear and actually increasing at the same rate (and by the same increment) as the capacity increase. This is probably due to economy-wide interactions that create synergetic effects of better availability of electricity that enables deployment of new technologies and increased investments in new industries. This trend is unlikely to continue, but it is worth emphasizing that the early phase of electric power development has the highest returns to scale.

It is also clear from the results that hydropower expansion serves as an insurance against oil price hike. Going down the columns (Table 5) indicates that lower oil prices will accelerate growth, with the same hydropower capacity. This may be due to two reasons: (i) lower oil prices facilitate transport and other liquid fuel-driven economic activities and (ii) they provide opportunities for cheaper electricity imports from neighboring countries. The higher hydropower capacity also reduced the importance of conventional energy prices as a risk factor for the macro economy. In the low hydropower case (last column), the growth impact falls by $50 \%$ (from $25 \%$ to $13 \%$ ) as oil prices double. In the Hydro20 case (first column), the growth dividend falls by less than $8 \%$ as oil prices double. These results make it clear that hydropower expansion not only promotes growth but also guards against oil price hikes. Moreover, the dividends of export competitiveness and environmental sustainability (less air pollution, climate change mitigation, and possible flood control and seasonal water arbitrage) should make this Hydro20 investment strategy a high priority.

The purpose of having two different $\mathrm{GQ}$ estimates is to examine the robustness of the results as underlined probability distribution assumptions changes. As fully explained in H. Gunatilake and RolandHolst (2013), two types of error distribution assumptions were made in the two methods. The Legendre approach assumes uniform distribution, whereas Hermite assumes normal distribution. In the present context, this leads to a slight variation in results in the reference (Hydro20) scenario, but has no effect on our qualitative findings or recommendations. Very similar results with different assumptions about distribution of uncertainty show the robustness of the results. 

Table 5: Stochastic Scenario Estimates Percent Change
in Real GDP Baseline 2030, Legendre Method

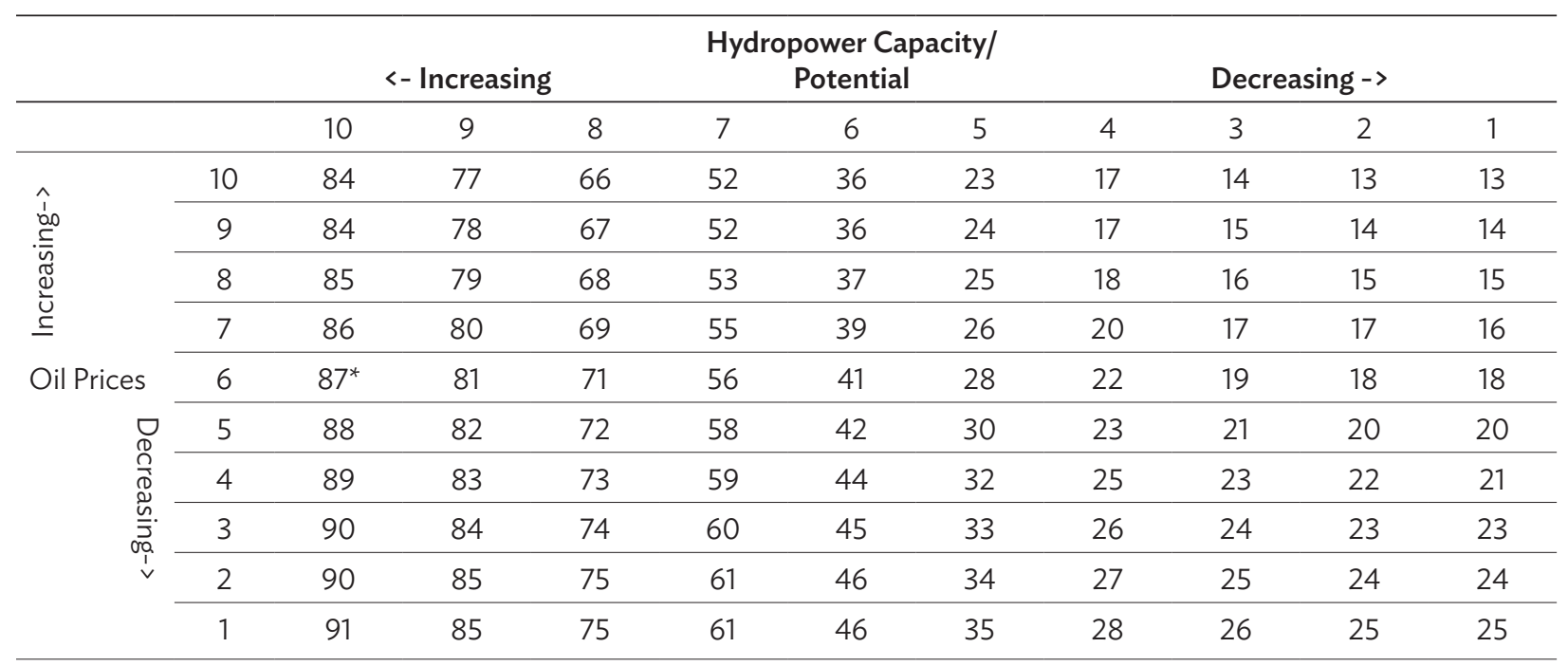

GDP = gross domestic product.

Notes: Column and row numbers represent varying scenario and oil price values (respectively).

Scenario: 2030 hydropower varies from $20 \%$ of potential (first column) to $5 \%$.

Oil: 2030 price varies from $200 \%$ of 2010 (first row) to $50 \%$.

* denotes the reference Hydro2030 scenario.

Source: Author's Estimates

Table 6: Stochastic Scenario Estimates

Percent Change in Real GDP Baseline 2030, Hermite Method

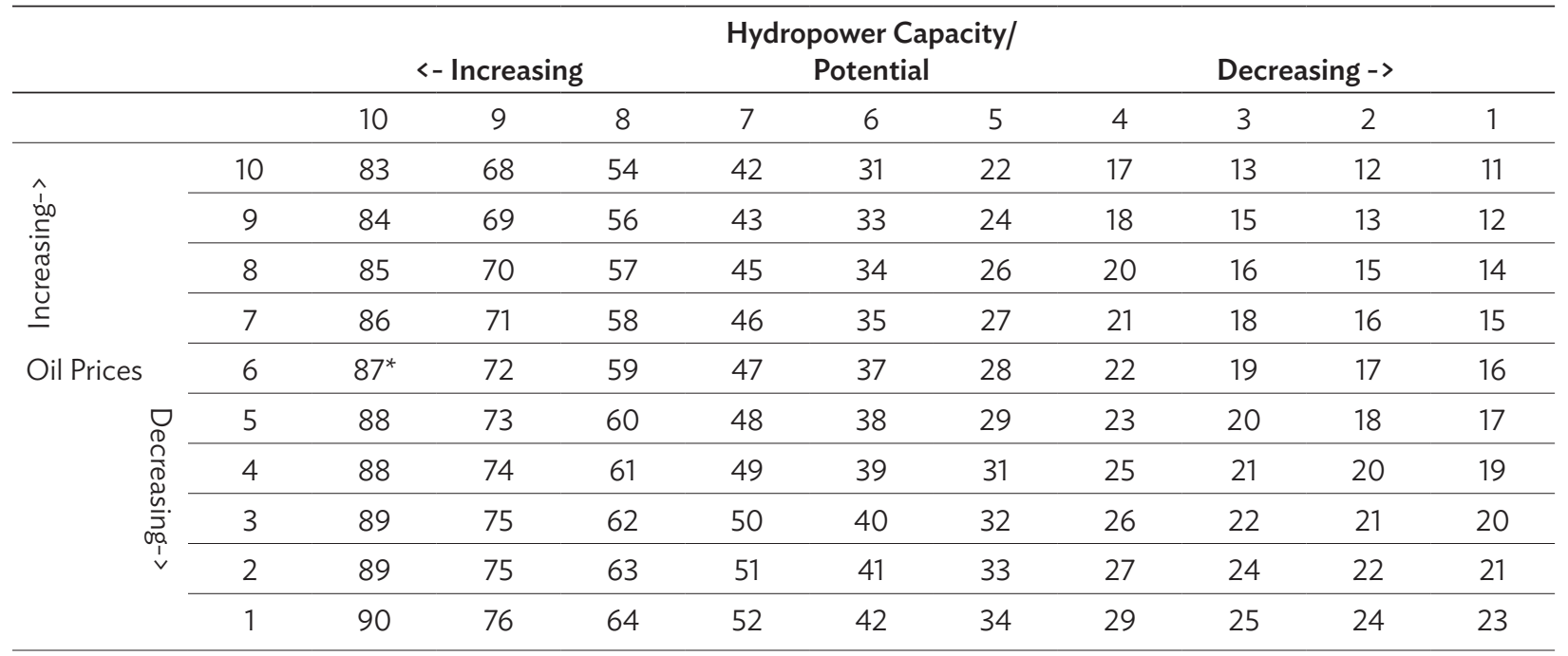

GDP = gross domestic product.

Notes: Column and row numbers represent varying scenario and oil price values (respectively).

Scenario: 2030 hydropower varies from $20 \%$ of potential (first column) to $5 \%$.

Oil: 2030 price varies from $200 \%$ of 2010 (first row) to $50 \%$.

* denotes the reference Hydro2030 scenario.

Source: Author's Estimates 


\section{CONCLUSIONS}

Nepal is endowed with huge hydropower potential. Being a landlocked country with no known fossil fuel resources signifies the importance of water resources. Despite some recent successful efforts to use these vast water resources for its development, Nepal has not been able to use this enormous resource fully for its economic development. It is strange that the country has an underperforming power sector with supply shortages, reliability issues, and poor access to electricity, while sitting on an enormous potential to produce hydropower. Adequate supply of power with acceptable quality is a precondition for any nation to modernize its economy and to sustain economic growth. Nepal's electric power sector has been trapped in low-level investment equilibrium, the only path to exit from this is injection of public, domestic private, and external agency investment in hydropower development. This situation is changing since 2016, but more concerted efforts through public intervention are needed to overcome barriers to develop hydropower resources in the country.

In this context, this paper examines the macroeconomic implications of a substantial hydropower generation expansion in the country, including transmission resources that could serve external markets. Using a state-of-the-art computable general equilibrium (CGE) model, the paper examines the consequences of Nepal realizing merely $20 \%$ of its economically viable hydropower potential. The results convincingly suggest that the electric power sector, which had been an impediment to growth, could become a dramatic growth catalyst, increasing real gross domestic product (GDP) by $87 \%$ above baseline values by 2030. Further, the results show that hydropower expansion can be a hedge against the negative growth impact of oil price shocks. While higher oil prices dampen the positive growth impacts, aggressive expansion of hydropower generation provides considerable economic growth benefits.

This paper has applied an advanced hybrid of the Monte Carlo method to undertake sensitivity analysis. Realization of various degrees of hydropower expansion and oil price shocks was considered as risks in the sensitivity. Sensitivity analysis confirms the basic results, and provides additional insights about the interactive effects of exogenous oil price shocks and varying degrees of hydropower development. Similar results with two different error distribution assumptions also affirm the robustness of the results. Particularly in the case of large-scale, long-term investment policies and projects, it would be advisable to apply similar Monte Carlo methods like this to improve understanding of policy resilience and vulnerability. 


\section{REFERENCES}

S. Agrawala et al. 2003. Development and Climate Change in Nepal: Focus on Water Resources and Hydropower. Paris: OECD.

C. Agreira et al. 2006. "Probabilistic Steady-State Security Assessment of an Electric Power System Using A Monte Carlo Approach," UPEC '06. Proceedings of the 41st International, Volume 2, pp. 408-411, 6-8 September.

A. Ansar et al. 2014. Should we build more large dams? The actual costs of hydropower megaproject development. Energy Policy, 69: pp. 43-56.

C. Arndt. 1996. "An Introduction to Systematic Sensitivity Analysis via Gaussian Quadrature," GTAP Technical Paper No. 2. Purdue University.

Asian Development Bank. 2013. Nepal: Tanahu Hydropower Project. All project documents available at http://www.adb.org/projects/43281-013/main.

D. Billington and D. Jackson. 2007. Big Dams of the New Deal Era: A Confluence of Engineering and Politics. Environmental History, Volume 12 (3). pp. 683-684, https://doi.org/10.1093/envhis/12.3.683.

R. Booth. 1972. Power System Simulation Model Based on Probability Analysis. IEEE Trans. Power Appar. Syst., PAS-91 pp. 62-69.

A. Breipohl et al. 1990. Sample size reduction in stochastic production simulation, IEEE Trans. Power Syst., 5 (3) pp. 984-992.

R. Cruzet al. 2007. Asia. In M. Parry etal. (eds.) Climate Change 2007: Impacts, Adaptation and Vulnerability. Contribution of Working Group II to the Fourth Assessment Report of the Intergovernmental Panel on Climate Change. Cambridge University Press.

H. Gunatilake and D. Roland-Holst. 2013. A Dynamic Economic Forecasting Model for Nepal: Technical Documentation. Discussion Paper, Department of Agricultural and Resource Economics. UC Berkeley.

A. Gurung and S. Oh. 2013. Conversion of Traditional Biomass into Modern Bioenergy Systems: A Review in Context to Improve the Energy Situation in Nepal. Renewable Energy. Volume 50 (C). pp. 206-213.

A. Gurung et al. 2012. The Prospects of Renewable Energy Technologies for Rural Electrification: A Review from Nepal. Energy Policy. Volume 40 (C). pp. 374-380.

A. Gurung et al. 2011. The Potential of a Renewable Energy Technology for Rural Electrification in Nepal: A Case Study from Tangting. Renewable Energy. Volume 36. pp. 3203-3210.

A. Gurung et al. 2013. Roles of Renewable Energy Technologies in Improving the Rural Energy Situation in Nepal: Gaps and Opportunities. Energy Policy. Volume 62. pp. 1104-1109.

C. Hermeling et al. 2013. A New Robustness Analysis for Climate Policy Evaluations: A CGE Application for the EU 2020 Targets. Energy Policy. Volume 55. pp. 27-35. 
A. Hughes. 2011. Meeting Report: Hydro 2010 Conference, Lisbon, Portugal, September 2010. Dams and Reservoirs. Volume 21 (1). pp. 5-5. https://doi.org/10.1680/dare.2011.21.1.5.

W. Immerzeel et al. 2009. Large-Scale Monitoring of Snow Cover and Runoff Simulation in Himalayan River Basins Using Remote Sensing. Remote Sensing of Environment. Volume 113 (1). pp. 40-49.

F. Lee et al. 1990. Evaluation of the Variance of Production Cost Using a Stochastic Outage Capacity State Model. IEEE Transactions on Power Systems. Volume 5 (4). pp. 1061-1067.

M. Mazumdar and A. Kapoor. 1995. Stochastic Models for Power Generation System Production Costs. Electric Power Systems Research. Volume 35 (2). pp. 93-100.

Government of Nepal, Ministry of Finance. 2011. Economic Survey: Fiscal Year 2010/11. Kathmandu.

Government of Nepal, Ministry of Finance. 2012. Economic Survey: Fiscal Year 2011/12. Kathmandu.

A. Nakarmi et al. 2003. Energy Scenarios of Nepal 2010-2030: A Renewable and Sustainable Approach. Proceedings of the International Conference on Energy Resources and Technologies for Sustainable Development. West Bengal, India.

Nepal Electricity Authority (NEA). 2010. Annual Report of Nepal Electricity Authority: Fiscal Year 2009/2010. Kathmandu.

NEA. 2011. A Year in Review: Fiscal Year 2010/11. Kathmandu.

NEA. 2012. A Year in Review: Fiscal Year 2011/12. Kathmandu.

NEA. 2019. A Year in Review: Fiscal Year 2018/19. Kathmandu.

R. Nepal. 2012. Roles and Potentials of Renewable Energy in Less-Developed Economies: The Case of Nepal. Renewable and Sustainable Energy Reviews. Volume 16. pp. 2200-2206.

R. Nepal and T. Jamasb. 2013. Caught Between Theory and Practice: Government, Market and Regulatory Failures in Electricity Sector Reforms. EPRG Working Paper 1304. Cambridge, UK: Electricity Policy Research Group, University of Cambridge.

R. Nepal and T. Jamasb. 2012. Reforming Small Electricity Systems Under Political Instability: The Case of Nepal. Energy Policy. Volume 40. pp. 242-251.

A. Scully et al. 1992. Using a Semi-Guided Monte Carlo Method for Faster Simulation of Forced Outages of Generating Units. IEEE Transactions on Power Systems. Volume 7 (3). pp. 1313-1321.

R. Sharma and R. Awal. 2013. Hydropower Development in Nepal. Renewable and Sustainable Energy Reviews. Volume 21. pp. 684-693.

B. Sovacool et al. 2011. Electrification in the Mountain Kingdom: The Implications of the Nepal Power Development Project. Energy for Sustainable Development. Volume 15. pp. 254-265.

B. Sovacool et al. 2011. Halting Hydro: A Review of the Socio-Technical Barriers to Hydroelectric Power Plants in Nepal. Energy. Volume 36. pp. 3468-3476. 
C. Spezia. 2009. Monte Carlo Analysis of Real-Time Electricity Pricing for Industrial Loads. Journal of Industrial Technology. Volume 25 (3). July-September.

K. Surendra et al. 2011. Current Status of Renewable Energy in Nepal: Opportunities and Challenges. Renewable and Sustainable Energy Reviews. Volume 15. pp. 4107-4117.

World Commission on Dams. 2000. Dams and Development: A New Framework for Decision-Making. UK: Thanet Press.

D. Vose. 1996. Quantitative Risk Analysis: A Guide to Monte Carlo Simulation Modelling. Wiley: Chichester.

World Bank. 2009. Directions in Hydropower. Washington, DC. http://documents.worldbank.org/curated/ en/164581468336679451/Directions-in-hydropower 


\section{Hydropower Development and Economic Growth in Nepal}

Hydropower has the potential to play an important role in South Asia, which faces growing demand for clean, reliable, and affordable energy. However, environment and social impacts raised serious concerns about hydropower during the 1990s, and many development agencies reduced their support for hydropower. Growing concerns about climate change has renewed interest on hydropower. This paper assesses the economic and environmental benefits of hydropower development considering Nepal as a case study. It shows that developing a part of Nepal's hydropower potential results in stronger economic growth and significantly reduces poverty while delivering environmental benefits and climate change mitigation.

\section{About the Asian Development Bank}

ADB is committed to achieving a prosperous, inclusive, resilient, and sustainable Asia and the Pacific, while sustaining its efforts to eradicate extreme poverty. Established in 1966, it is owned by 68 members -49 from the region. Its main instruments for helping its developing member countries are policy dialogue, loans, equity investments, guarantees, grants, and technical assistance. 